\title{
PUTUSAN MAHKAMAH KONSTITUSI TENTANG STATUS ANAK LUAR NIKAH DAN KEKUATAN HUKUMNYA
}

\author{
Dadan Muttaqien \\ Fakultas IAI Universitas Islam Indonesia \\ Muhammad Arif Zuhri
}

\begin{abstract}
The problem of lineage, in relation to Islam, is getting important to be discussed and to be given sufficient attention by Muslims today. This situation is driven by the verdict of the Indonesian Constitutional Court No. 46/PUU-VIII/2010 on the case of children which were born outside marital relation. The said verdict has been considered as controversial and led to prolonged polemics in the society, and particularly among Muslims. This due to the content of the verdict that is not within the boundary of the established norm in Islamic law. One of the negative effects that seems to happen is that adultery will be justified by such verdict, since the children born as result of this adultery is considered as legal from the civil law perspective. This article tries to analyse the topic from the perspective of Islamic law. The article concludes that such verdict has not carry any legal power if it put in the context of Islamic law.
\end{abstract}

Key words: mahkamah konstitusi, status anak, luar nikah

\section{PENDAHULUAN}

Hukum Islam dalam konsepsi orang Muslim merupakan kategori normatif yang harus dipatuhi. ${ }^{1}$ Hukum Islam merupakan lambang pemikiran Islam dan manifestasi paling khusus dari pandangan hidup Islam serta inti dan titik sentral dari Islam itu sendiri. Hukum Islam adalah bagian dari Islam itu sendiri sehingga ia bersumber dari agama Islam dan tidak mungkin bertentangan dengannya. Oleh karena itu, tidak mungkin seseorang bisa memahami Islam tanpa memahami hukumnya. ${ }^{2}$ Pernyataan ini menunjukkan betapa Hukum Islam memiliki peranan yang penting, kedudukan tinggi, dan kekuatan yang besar bagi setiap umat Islam.

Hukum Islam ${ }^{3}$ merupakan kumpulan tata aturan yang mencakup semua perbuatan hukum yang dilakukan oleh manusia baik dalam hubungannya dengan Tuhan sebagai alKhaliq maupun dengan sesama manusia baik di dalam lingkungannya yang terbatas ataupun di luar lingkungannya. Hukum Islam mencakup berbagai persoalan hidup manusia, baik yang menyangkut urusan dunia maupun urusan akhirat. Dengan demikian, ia mengatur kehidupan manusia di setiap lini kehidupan tidak hanya sebagai individu, tetapi lebih dari itu adalah sebagai makhluk sosial.

Keluarga merupakan komunitas terkecil dalam struktur sosial. Meskipun demikian, ia memiliki posisi amat signifikan dan strategis dalam memberikan warna bagi sebuah masyarakat. Baik atau buruk suatu masyarakat sangat bergantung pada kualitas keluarga-keluarga yang ada di dalamnya. Keluarga adalah cikal bakal peradaban manusia. ${ }^{4}$ Oleh karena itu, tidaklah

\footnotetext{
1 Syamsul Anwar, Epistemologi Hukum Islam dalam al-Mustasfa min 'Ilm al-Usul Karya al-Gazzali (450-505 H/1058-1111 M), Disertasi, tidak diterbitkan (Yogyakarta: PPs. UIN Sunan Kalijaga, 2000), hlm. 1.

2 Joseph Schacht, An Introduction to Islamic Law (Oxford: Clarendon Press, 1964), hlm. 1.

3 Hukum Islam memiliki identitas ganda. Ini terlihat dalam dua penunjukan bahasa arabnya, syari 'ah dan figh. Pembahasan lebih lanjut tentang Hukum Islam akan diuraikan dalam Bab II.

4 Nasaruddin Umar, "Kata Pengantar" untuk M. Nurul Irfan, Nasab \& Status Anak dalam Hukum Islam (Jakarta: Amzah, 2012), hlm. ix.
} 
heran apabila al-Qur'an mengingatkan lewat ayatnya agar setiap orang yang beriman menjaga keluarganya, setelah dirinya sendiri, dari api neraka (simbol keburukan dan kenistaan). ${ }^{5}$

Unsur utama keluarga menurut Hukum Islam adalah nasab (keturunan atau pertalian keluarga). ${ }^{6}$ Allah menegaskan bahwa nasab merupakan karuniaNya ${ }^{7}$ sehingga ia harus dijaga sebaik mungkin. Oleh karena itu, dengan konsep maqashiid asy-syari'ah Islam mementingkan terjaganya lima hal dasar (al-kulliyyat al-khamsah), yaitu agama, jiwa, akal, harta, dan juga keturunan. ${ }^{8}$ Begitu pentingnya status nasab, Hukum Islam telah mensyari'atkan perkawinan dengan segala formula dan rukun serta syaratnya ${ }^{9}$ sebagai satu-satunya jalan untuk memelihara dan mengesahkan nasab tersebut. Tanpa perkawinan yang sah, dalam Hukum Islam tidak dibenarkan membangun keturunan dalam keluarga. Bersamaan dengan perintah nikah, Islam mengharamkan zina ${ }^{10}$ karena bisa menyebabkan tidak terpeliharanya nasab secara sah. Ini menegaskan bahwa Islam sangat menaruh perhatian untuk menata sosial secara baik dan benar.

Persoalan nasab dalam kajian hukum di Indonesia akhir-akhir ini menjadi menarik dan penting untuk diperhatikan, khususnya setelah Mahkamah Konstitusi (MK) mengeluarkan putusan yang sangat kontroversi tentang status anak luar nikah. Putusan yang dimaksud adalah Putusan Mahkamah Konstitusi Nomor 46/PUU-VIII/2010. Putusan ini melahirkan polemik yang berkepanjangan di masyarakat. Putusan ini oleh berbagai kalangan dianggap meresahkan karena memungkinkan timbulnya penafsiran yang keluar dari aturan yang telah ditetapkan oleh Hukum Islam, yaitu pelegalan perzinaan. Menanggapi hal yang demikian, Majelis Ulama Indonesia (MUI) terpanggil untuk mengkaji Putusan Mahkamah Konstitusi tersebut hingga akhirnya Majelis Ulama Indonesia mengeluarkan Fatwa Nomor 11 Tahun 2012 Tentang Kedudukan Anak Hasil Zina dan Perlakuan Terhadapnya. Majelis Ulama Indonesia menilai bahwa Putusan Mahkamah Konstitusi tersebut telah melampaui batas dan tidak sesuai dengan agama Islam dan Pasal 29 Undang-Undang Dasar Negara Republik Indonesia Tahun $1945 .{ }^{11}$

Sebagai warga negara yang baik, setiap warga negara Indonesia memiliki keharusan untuk mematuhi perundang-undangan yang berlaku di Indonesia. Putusan Mahkamah Konstitusi merupakan salah satu dari perundang-undangan tersebut. Tetapi, pada sisi yang lain, Hukum Islam merupakan aturan pertama dan utama yang harus dipatuhi oleh setiap

\footnotetext{
5 Allah berfirman dalam Q.S. at-Tahrlm (66): 6:
}

"Wahai orang-orang yang beriman! Peliharalah dirimu dan keluargamu dari api neraka yang bahan bakarnya adalah manusia dan batu...". Departemen Agama R.I., al-Qur'an dan Terjemahnya (Surakarta: Media Insani Publishing, t.th.), hlm. 560.

6 Nasaruddin Umar, "Kata Pengantar", him. ix.

7 Allah berfirman dalam Q.S. al-Furqa>n (25): 54.

"Dan Dia (pula) yang menciptakan manusia dari air, lalu Dia jadikan manusia itu (mempunyai) keturunan dan mus\}a $>$ harah dan Tuhanmu adalah Maha Kuasa". Yang dimaksud dengan mus /a>harah adalah hubungan kekeluargaan yang berasal dari hubungan pernikahan, seperti menantu, ipar, mertua, dan sebagainya. Departemen Agama R.I., al-Qur'an dan Terjemahnya, hlm. 364-365.

- Abu Ishaq asy-Syatibi, al-Muwafaqat fi Usul asy-Syari'ah, vol. Il (Mesir: Daar al-Fikr, 1341 H.), hlm. 5.

9 Fuqaha' (ulama fikih) berbeda pendapat tentang rukun dan syarat nikah. Menurut analisa Wahbah az-Zuhaili, dari sekian rukun nikah yang ada, hanya ada dua rukun perkawinan yang disepakati oleh fuqaha' yaitu ijab dan kabul. Sebab, hanya kedua hal ini yang masuk klasifikasi rukun dalam pandangan fuqaha' Hanafiyah, sedangkan sisanya hanyalah syarat perkawinan. Menurut jumhur fuqaha', rukun perkawinan ada empat yaitu $s$; $>$ gat (ijab dan kabul), calon isteri, calon suami, dan wali. Lihat Wahbah az-Zuhaili, al-Fiqh al-Isla>mi> wa Adillatuh, cet. ke-3 (Damaskus: Daar al-Fikr, 1989 ), vol. VII, hlm. 36.

${ }^{10}$ Allah berfirman dalam Q.S. al-Isra>' (17): 32:

\footnotetext{
“Dan janganlah kamu mendekati zina; (zina) itu sungguh suatu perbuatan keji, dan suatu jalan yang buruk". Departemen Agama R.I., al-Qur'an dan Terjemahnya, hlm. 285.

11 "MUI : Putusan MK Soal Status Anak di Luar Nikah Melampaui Batas". dalam http://www.islamedia.web.id/2012/03/muiputusan-mk-soal-status-anak-di-luar.html, diakses 12 Februari 2013.
} 
umat Islam karena ia bersumber dari titah (khithab) Allah swt. Masing-masing hukum tersebut (Putusan Mahkamah Konstitusi dan Hukum Islam) memiliki kekuatan hukum tersendiri untuk ditaati dan dipatuhi.

Sebagaimana disebutkan sebelumnya, Putusan Mahkamah Konstitusi Nomor 46/PUUVIII/2010 tersebut dinilai telah menabrak aturan yang telah ditetapkan oleh Hukum Islam. Melihat kenyataan yang demikian, karena Putusan Mahkamah Konstitusi dan Hukum Islam memiliki kekuatan hukum tersendiri, menarik untuk dikaji sejauh mana kekuatan Putusan Mahkamah Konstitusi tersebut jika dihadapkan dengan Hukum Islam yang menjadi pegangan dan landasan beragama bagi umat Islam di Indonesia.

\section{POKOK MASALAH}

Untuk mendalami masalah yang telah dipaparkan sebelumnya dan untuk mengarahkan pengkajian, maka kajian diarahkan kepada sebuah pertanyaan yaitu bagaimana posisi Putusan Mahkamah Konstitusi Nomor 46/PUU-VIII/2010 Tentang Status Anak Luar Nikah jika dihadapkan dengan ketentuan Hukum Islam?

\section{PUTUSAN MAHKAMAH KONSTITUSI NOMOR 46/PUU-VIII/2010 DALAM PERSPEKTIF YURIDIS, NORMATIF, DAN SOSIOLOGIS}

Dari sekian banyak kewenangan yang dimiliki oleh Mahkamah Konstitusi, kewenangan yang paling banyak mendapat perhatian adalah kewenangan mengadili pada tingkat pertama dan terakhir yang putusannya bersifat final untuk menguji Undang-Undang terhadap UndangUndang Dasar. Hal ini dikenal dengan istilah judicial review. ${ }^{12}$ Putusan Mahkamah Konstitusi Nomor 46/PUU-VIII/2010 merupakan hasil dari judicial review.

Penjelasan Pasal 10 Undang-Undang Nomor 24 Tahun 2003 Tentang Mahkamah Konstitusi menegaskan bahwa putusan Mahkamah Konstitusi bersifat final. Artinya Putusan Mahkamah Konstitusi langsung memperoleh kekuatan hukum tetap sejak diucapkan dan tidak ada upaya hukum yang dapat ditempuh. ${ }^{13}$ Untuk itu, di dalam mengeluarkan putusan, Mahkamah Konstitusi harus benar-benar berhati-hati dan penuh pertimbangan serta menjaga asas-asas atau patokan-patokan yang telah ada agar aturan yang dikeluarkan mengandung kemaslahatan bagi khalayak luas. Untuk itu, tinjauan yuridis, normatif, dan sosiologis berikut mencoba untuk menggali sejauh mana Putusan Mahkamah Konstitusi Nomor 46/PUUVIII/2010 sejalan dengan perundang-undangan yang berlaku di Indonesia, sejalan dengan Hukum Islam, dan sejauh mana gerak masyarakat merespon hadirnya putusan tersebut.

Tetapi tidak dapat dipungkiri bahwa putusan Mahkamah Konstitusi tersebut juga telah melahirkan berbagai kontroversi dan polemik yang berkepanjangan. Untuk itu, analisis kritis terhadapnya perlu dilakukan. Ini bertujuan untuk mengetahui apakah benar ia melindungi hak-hak anak yang terlahir di luar nikah, ataukah menimbulkan persoalan yang lebih besar dibanding melindungi hak-hak anak tersebut. Uraian berikut menganalisis Putusan Mahkamah Konstitusi tersebut dalam tiga tinjauan yaitu tinjauan yuridis, normatif, dan sosiologis.

\section{Tinjauan Yuridis}

Hasil analisis yuridis terhadap Putusan Mahkamah Konstitusi Nomor 46/PUU-VIII/2010 adalah sebagai berikut.

\footnotetext{
${ }^{12}$ Judicial review adalah pengujian oleh lembaga yudikatif tentang konsistensi Undang-Undang (UU) terhadap UndangUndang Dasar (UUD) atau peraturan perundang-undangan terhadap peraturan perundang-undangan yang lebih tinggi. Judicial review dimaksudkan untuk menjamin konsistensi materi setiap jenjang peraturan perundang-undangan dengan cita-cita dan tujuan negara dalam rangka pembangunan sistem hukum. Moh. Mahfud MD, Membangun Politik Hukum, Menegakkan Konstitusi, cet. ke-2 (Jakarta: PT RajaGrafindo Persada, 2011), hlm. 37-40.

${ }^{13}$ Lihat Undang-Undang Nomor 24 Tahun 2003 Tentang Mahkamah Konstitusi.
} 


\section{a. Pelanggaran asas non ultra petita/ultra petitum partium (membuat ultra petita)}

Sebelumnya telah dijelaskan bahwa ultra petita dalam hukum formil mengandung pengertian sebagai penjatuhan putusan atas perkara yang tidak dituntut atau mengabulkan lebih daripada yang diminta. ${ }^{14}$ Mahfud MD menegaskan bahwa di antara asas atau patokan yang harus dipegang oleh Mahkamah Konstitusi sebagai "pengawal konstitusi" dalam melaksanakan hak uji materi adalah bahwa dalam membuat putusan, Mahkamah Konstitusi tidak boleh memutus hal-hal yang tidak diminta (ultra petita). ${ }^{15}$ Betapapun Mahkamah Konstitusi melihat ada sesuatu. yang penting dalam sebuah permintaan dan dianggap penting untuk diminta maka jika hal itu tidak diminta untuk diuji, Mahkamah Konstitusi tidak boleh melakukannya. Jika hal itu dilakukan oleh Mahkamah Konstitusi, maka selain melanggar prinsip bahwa Mahkamah Konstitusi hanya boleh memutus hal yang secara jelas diminta, Mahkamah Konstitusi juga telah melanggar asas umum di dalam hukum bahwa setiap permintaan pemeriksaan harus diuraikan dalam "posita" yang jelas yang juga dimuat di dalam Peraturan Mahkamah Konstitusi sendiri. ${ }^{16}$

Ada yang memiliki perbedaan pendapat dengan Mahfud. Jimly Asshiddiqie membedakan antara ultra petita dalam hukum perdata dan hukum pidana. Menurutnya, larangan membuat ultra petita itu hanya ada di dalam hukum perdata, apalagi jika hal itu menyangkut sebuah pengujian atas satu Pasal Undang-Undang yang berkaitan juga dengan pasal-pasal lain di dalam Undang-Undang yang diuji yang bahkan mungkin juga menjadi jantung Undang-Undang tersebut. Sedangkan di dalam hukum pidana, ultra petita dibolehkan. ${ }^{17}$ Sementara itu, Bagir Manan menyatakan bahwa Mahkamah Konstitusi boleh membuat putusan ultra petita asalkan sejak awal pemohon pengujian menyebut "et aequo et bono" di dalam permohonannya. Artinya, pemohon minta putusan yang adil sehingga Mahkamah Konstitusi dapat membuat putusan yang adil itu meski tidak diminta. ${ }^{18}$ Namun, Mahfud menolak pendapat ini dan tetap berpegang pada pendapatnya bahwa Mahkamah Konstitusi tidak boleh membuat ultra petita dalam keadaan apapun. Alasannya adalah karena membuat ultra petita itu berarti masuk ke ranah legislatif atau produk legislasi yang tidak dipersoalkan. Kalau Mahkamah Konstitusi boleh membuat ultra petita berarti Mahkamah Konstitusi boleh membatalkan isi Undang-Undang yang tidak diminta dalam pengujian sekalipun. ${ }^{19}$

Dari berbagai pendapat dan argumen yang diberikan, kiranya dapat disimpulkan dan dipahami bahwa Mahkamah Konstitusi telah diberi kewenangan khusus dan terbatas sebagaimana tertuang dalam Undang-Undang Nomor 24 Tahun 2003 Tentang Mahkamah Konstitusi dan Mahkamah Konstitusi tidak boleh keluar dari kewenangannya tersebut. Membuat ultra petita menyebabkan Mahkamah Konstitusi memasuki ranah lain yang berada di luar kewenangannya. Untuk itu, pendapat yang menegaskan bahwa Mahkamah Konstitusi tidak boleh membuat ultra petita lebih menjaga batas-batas kewenangan Mahkamah Konstitusi.

Menelaah Putusan Mahkamah Konstitusi Nomor 46/PUU-VIII/2010 melalui asas ultra petitum partium, ditemukan bahwa Mahkamah Konstitusi telah memutus hal-hal yang tidak diminta (ultra petita) atau telah melanggar asas ultra petitum partium. ${ }^{20}$ Ini terlihat

${ }^{14} \mathrm{TIm}$ Penyusun, Hukum Acara Mahkamah Konstitusi (Jakarta: Sekretariat Jenderal dan Kepaniteraan Mahkamah Konstitusi Republik Indonesia bekerja sama dengan Asosiasi Pengajar Hukum Acara Mahkamah Konstitusi, 2010 ), hlm. 34.

${ }^{15}$ Moh. Mahfud MD, Perdebatan Hukum Negara Pasca Amandemen Konstitusi, cet. ke-2 (Jakarta: PT RajaGrafindo Persada, 2011), him. 101.

16 Ibid.

17 lbid.

18 Ibid.

19 lbid., him. 101-102.

20 Dadan Muttaqien, "Keputusan Mahkamah Konstitusi Republik Indonesia No. 46/PUU-VIII/2010 Tanggal 13 Februari 2012 Tentang Pengujian Terhadap Pasal 2 Ayat (2) dan Pasal 43 Ayat (1) Undang-Undang No. 1 Tahun 1974 Tentang Perkawinan dalam Perspektif Hukum Perdata Indonesia", Makalah, tidak diterbitkan, dlsampaikan pada seminar regional 22 Maret 2012 yang diadakan oleh Fakultas IImu Agama Islam (FIAI) Universitas Islam Indonesia (UII) Yogyakarta dalam mensikapi Putusan 
jelas dari amar putusannya yang menyatakan "...mempunyai hubungan darah, termasuk hubungan perdata dengan keluarga ayahnya". Inti dari hal yang diminta oleh pemohon dalam masalah ini adalah adanya kepastian hukum (kedudukan hukum) bagi Muhammad Iqbal Ramadhan. Dari kutipan amar putusan di atas, Putusan Mahkamah Konstitusi ini telah menetapkan lebih dari sekedar mempunyai kepastian hukum (kedudukan hukum) bagi Muhammad Iqbal Ramadhan. Putusan ini juga telah menetapkan bahwa Muhammad Iqbal Ramadhan memiliki hubungan darah dan hubungan perdata tidak hanya dengan dengan ayah biologis Muhammad lqbal Ramadhan, Moerdiono.

Selain itu, kasus yang dipermasalahkan terjadi dalam rangkaian pernikahan siri. ${ }^{21}$ Sedangkan putusan ini tidak hanya memiliki kaitan dengan pernikahan siri, tetapi juga memiliki dampak luas kepada pengakuan hubungan perdata bagi setiap anak yang lahir di luar perkawinan atau hasil dari hubungan zina dengan berbagai variannya. ${ }^{22}$ Tentu hal ini juga telah menjadikan Mahkamah Konstitusi melanggar asas non ultra petita (ultra petitum partium).

Menurut Yahya Harahap, hakim yang mengabulkan tuntutan melebihi posita maupun petitum gugatan dianggap telah melampaui wewenang atau ultra vires, yakni bertindak melampaui wewenangnya. Apabila putusan mengandung ultra petita, maka putusan tersebut harus dinyatakan cacat meskipun hal itu dilakukan hakim dengan itikad baik (good faith) maupun sesuai dengan kepentingan umum (public interest). ${ }^{23}$ Maka, putusan Mahkamah Konstitusi Nomor 46/PUU-VIII/2010 dapat dinyatakan cacat karena melanggar asas ultra petitum partium atau membuat ultra petita.

\section{b. Kurang memperhatikan keadilan dan kepentingan umum}

Obyek hukum acara perdata ${ }^{24}$ di Mahkamah Konstitusi berbeda dengan di peradilan perdata yang melindungi orang-perorang. Obyek hukum acara perdata di Mahkamah Konstitusi lebih bersifat hukum publik. Hal ini sesuai dengan obyek pengujiannya yaitu ketentuan Undang-Undang sebagai norma yang bersifat abstrak dan mengikat secara umum. Dalam hal pengujian Undang-Undang misalnya, jelas bahwa perkara ini menyangkut kepentingan umum yang akibat hukumnya mengikat semua orang (erga omnes). ${ }^{25}$ Oleh karena itu, putusan yang ditetapkan oleh Mahkamah Konstitusi harus menjamin rasa keadilan dan kepentingan umum.

Putusan Mahkamah Konstitusi Nomor 46/PUU-VIII/2010 memang telah menjaga dan melindungi hak-hak pemohon. Tetapi, di lain sisi, Mahkamah Konstitusi telah tidak menjaga dan tidak melindungi hak-hak mereka yang berada di luar pihak yang berperkara, khususnya keluarga Moerdiono. Keluarga Moerdiono tentunya merasa bahwa Machica telah merampas Moerdiono dari tangan mereka. Dengan mengetahui bahwa Moerdiono menikah siri dengan Machica saja telah menyebabkan keluarga Moerdiono merasa tidak bahagia dan dicurangi, apalagi ketika mereka harus mengakui adanya hubungan darah dan perdata dengan Muhammad Iqbal Ramadhan. Karena putusan Mahkamah Konstitusi bersifat final dan mengikat, maka secara hukum keluarga Moerdiono dituntut untuk

Mahkamah Konstitusi No. 46/PUU-IX/2011 tentang Tanggung Jawab Ayah Terhadap Anak Di Luar Nikah, him. 3.

21 Pernikahan siri antara Machica dan Moerdiono.

22 Seperti "kumpul kebo", selingkuh, pergundikan, dan lain-lain.

${ }_{23}$ M. Yahya Harahap, Hukum Acara Perdata tentang Gugatan, Persidangan, Penyitaan, Pembuktian, dan Putusan Pengadilan (Jakarta: Sinar Grafika, 2008), hlm. 801.

${ }^{24}$ Obyek hukum acara perdata adalah perkara yang disengketakan oleh para pihak serta proses pemecahannya melalui tahap persidangan sampai dengan putusan. Lihat Dadan Muttaqien, Dasar-Dasar Hukum Acara Perdata (Yogyakarta: insania Cita Press, 2006), him. 3.

${ }_{25}$ Tim Penyusun, Hukum Acara Mahkamah Konstitusi (Jakarta: Sekretariat Jenderal dan Kepaniteraan Mahkamah Konstitusi Republik Indonesia bekerja sama dengan Asosiasi Pengajar Hukum Acara Mahkamah Konstitusi, 2010$),$ hlm. 53. 
menerima Muhammad lqbal Ramadhan sebagai orang yang memiliki hubungan darah dan perdata dengan mereka. Hal ini akan sangat sulit diterima. Hingga kini, keluarga Moerdiono tetap tidak bisa menerima Putusan Mahkamah Konstitusi ini dan siap melakukan banding atas usaha yang dilakukan Machica. ${ }^{26}$

Selain dikhususkan pemberlakuannya bagi keluarga Moerdiono, Putusan Mahkamah Konstitusi tersebut juga berlaku bagi seluruh masyarakat Indonesia karena ia lebih bersifat hukum publik. Untuk itu, Putusan Mahkamah Konstitusi harus mencerminkan rasa keadilan dan ketertiban umum dengan menempatkan keyakinan-keyakinan yang hidup dalam masyarakat sebagai landasan. ${ }^{27}$ Putusan Mahkamah Konstitusi Nomor 46/ PUU-VII/2010 dipandang oleh begitu banyak masyarakat, dalam keyakinan yang hidup di dalamnya, sebagai hukum yang tidak memelihara keadilan dan ketertiban umum. Ini terlihat dari begitu banyaknya pendapat dan pandangan yang menentang Putusan Mahkamah Konstitusi tersebut karena dinilai bisa ditafsirkan adanya pelegalan perzinaan. ${ }^{28}$ Padahal, di antara hal yang ditakuti oleh mereka yang melakukan perzinaan dan menyebabkan mereka berpikir berulang-ulang untuk melakukan perzinaan adalah status hukum anak yang teriahir dari hubungan yang mereka lakukan tidak mendapat tempat di depan hukum dan masyarakat. Mereka akan merasa sangat malu. Ini yang menyebabkan mereka melakukan pengguguran kandungan. Dengan adanya Putusan Mahkamah Konstitusi ini, para pelaku zina, setidaknya, akan merasa aman untuk melakukan praktik zina karena anak yang terlahir dari hubungan tersebut tetap mendapat tempat dan terlindungi di depan hukum. Sedangkan tanpa dilindungi Undang-Undang pun praktik perzinaan sudah demlkian maraknya, apalagi Putusan Mahkamah Konstitusi ini bisa menjadi landasan yang kuat bagi pelaku zina. Dengan demikian, sudah pasti ketertiban umum yang dicita-citakan oleh adanya suatu aturan/hukum tidak dapat dicapai.

\section{c. Tidak menggunakan Hukum Perdata Islam}

Sistem hukum Indonesia, sebagai akibat dari perkembangan sejarahnya, bersifat majemuk atau plural. Sampai saat ini di Indonesia berlaku beberapa egara egar yang mempunyai corak dan susunan tersendiri. Sistem egar itu adalah egara Hukum Barat, egara Hukum Islam, dan egara Hukum Adat. Hukum Barat berlaku bagi orang Barat dan Timur Asing, Hukum Islam berlaku bagi orang Muslim, dan Hukum Adat berlaku bagi masyarakat Indonesia yang beragama non-Islam. ${ }^{29}$ Pemberlakuan tiga (3) egara egar ini merupakan konsekuensi dari konsep egara yang di dalamnya mengandung perlindungan terhadap hak-hak asasi manusia.

Putusan Mahkamah Konstitusi Nomor 46/PUU-VIII/2010 lahir akibat permohonan dari Machica dalam menuntut hak-hak perdata (status hukum) anak hasil perkawinan sirinya dengan Moerdiono. Sebagaimana telah diketahui, pihak-pihak yang berkaitan dengan lahirnya putusan

${ }^{26}$ Llhat komentar dari kuasa hukum alm. Moerdiono, Kartika Yososodiningrat, pada acara infotainment "Was-Was" dalam http://www. voutube.com/watch? $v=G W a s \times 29 k N i s$, diakses 4 Mei 2013.

${ }^{27}$ Prinsip-prinsip yang harus dikembangkan dalam mewujudkan hukum yang adil adalah menempatkan keyakinankeyakinan yang hidup dalam masyarakat sebagai landasan. Hukum harus diambil dari keyakinan yang hidup dalam masyarakat tentang suatu kehidupan yang adil. Lihat Theo Huijbers, Filsafat Hukum dalam Lintasan Sejarah (Yogyakarta: Kanisius, 1995), him. 69.

${ }^{28}$ Mengenai tanggapan atau respon dari Majelis Ulama Indonesia bisa dilihat misalnya "Fatwa MUI Tentang Kedudukan Anak Hasil Zina dan Perlakuan Terhadapnya", dalam http://www.voa-islam.com/news/indonesiana/2012/03/22/18307/ fatwa-mui-tentang-kedudukan-anak-hasil-zina-dan-perlakuan-terhadapnval: "MUI Nilai Keputusan MK Soal Status Anak di Luar Nikah Overdosis, dalam htto://news.detik.com/read/2012/03/13/164310/1866192/10/mui-nilaikeputusan-mk-soal-status-anak-di-luar-nikah-overdosis?9911012, diakses 11 Maret 2013.

${ }^{29}$ Hilman Hadikusuma, Hukum Perkawinan Indonesia Menurut Perundangan, Hukum Adat, Hukum Agama, cet. I (Bandung: Mandar Maju, 1990), hlm. 4-6. 
tersebut adalah orang Muslim. Sesuai dengan sistem hukum yang berlaku di Indonesia, karena inti persoalannya adalah antara warga negara Indonesia yang beragama Islam, maka seharusnya Mahkamah Konstitusi menggunakan dasar Hukum Perdata Islam. Tetapi, putusan Mahkamah Konstitusi tersebut bukanlah hasil dari penggunaan dasar Hukum Perdata Islam. ${ }^{30}$ Ini terlihat dari kata "hubungan perdata" yang termaktub dalam Amar Putusannya: ${ }^{31}$

"Anak yang dilahirkan di luar perkawinan mempunyai hubungan perdata dengan ibunya dan keluarga ibunya serta dengan laki-laki sebagai ayahnya yang dapat dibuktikan berdasarkan ilmu pengetahuan dan teknologi dan/atau alat bukti lain menurut hukum mempunyai hubungan darah, termasuk hubungan perdata dengan keluarga ayahnya". 32

\section{d. Tidak berpegang teguh pada hukum yang berlaku}

Merupakan hal yang telah diketahui bahwa pernikahan yang Moerdiono dengan Machica berlangsung pada saat Moerdiono telah mempunyai seorang isteri dan berada dalam hubungan pernikahan yang sah menurut Hukum Islam dan negara. Dengan demikian, Moerdiono telah melakukan praktik poligami. ${ }^{33}$

Perundang-undangan Indonesia telah mengatur tentang tata cara pelaksanaan pernikahan dan perceraian, di dalamnya termasuk aturan mengenai praktik poligami. Aturan ini terdapat dalam Undang-Undang Nomor 1 Tahun 1974 Tentang Perkawinan yang kemudian diatur dengan lebih jelas lagi melalui Peraturan Pemerintah Nomor 9 Tahun 1975 Tentang Pelaksanaan Undang-Undang Nomor 1 Tahun 1974 Tentang Perkawinan. Selain kedua perundang-undangan ini, terdapat aturan lain yang secara khusus mengatur tentang poligami bagi Pegawai Negeri Sipil (PNS). Peraturan yang dimaksud ialah Peraturan Pemerintah Nomor 10 Tahun 1983 Tentang Izin Perkawinan dan Perceraian Bagi Pegawai Negeri Sipil yang kemudian diubah dengan Peraturan Pemerintah Nomor 45 Tahun 1990 Tentang Perubahan Atas Peraturan Pemerintah Nomor 10 Tahun 1983 Tentang Izin Perkawinan dan Perceraian Bagi Pegawai Negeri Sipil. Khusus bagi umat Islam, diberlakukan Kompilasi Hukum Islam (KHI) sebagaimana Instruksi Presiden Nomor 1 Tahun 1991 kepada Menteri Agama untuk menyebarluaskan Kompilasi Hukum Islam dan Keputusan Menteri Agama Nomor 154 Tahun 1991 Tentang Pelaksanaan Instruksi Presiden Nomor 1 Tahun 1991.

Dalam Undang-Undang Nomor 1 Tahun 1974 Tentang Perkawinan, poligami diatur dalam Pasal 3, 4, dan 5. ${ }^{34}$ Dalam Peraturan Pemerintah Nomor 9 Tahun 1975 Tentang Pelaksanaan Undang-Undang Nomor 1 Tahun 1974 Tentang Perkawinan, poligami diatur dalam Pasal 40, 41, 42, 43, dan 44. ${ }^{35}$ Dalam Peraturan Pemerintah Nomor 10 Tahun 1983 Tentang Izin Perkawinan dan Perceraian Bagi Pegawai Negeri Sipil, poligami diatur dalam Pasal 4,5,6,7,8,9,10, dan $11 .^{36}$ Sedangkan dalam Peraturan Pemerintah Nomor 45 Tahun 1990 Tentang Perubahan Atas Peraturan Pemerintah Nomor 10 Tahun 1983 Tentang Izin

${ }^{30}$ Dadan Muttaqien, "Keputusan Mahkamah Konstitusi Republik Indonesia No. 46/PUU-VIII/2010 Tanggal 13 Februarl 2012 Tentang Pengujian Terhadap Pasal 2 Ayat (2) dan Pasal 43 Ayat (1) Undang-Undang No. 1 Tahun 1974 Tentang Perkawinan dalam Perspektif Hukum Perdata Indonesia", hlm. 4.

${ }^{31}$ lbid.

${ }^{32}$ Lihat Putusan Mahkamah Konstitusi Nomor 46/PUU-VIII/2010.

${ }^{33}$ Poligami berasal dari bahasa Yunani. Poligami merupakan penggalan dari poli atau polus yang artinya banyak, dan kata gamein atau gamos, yang berarti kawin atau perkawinan. Jika digabungkan akan berarti suatu perkawinan yang banyak, dan bisa jadi dalam arti yang tidak terbatas. Lihat Labib MZ, Pembelaan Umat Muhammad (Surabaya: Bintang Pelajar, 1986), hlm. 15. Pengertlan lain dari poligami adalah perkawinan antara seorang laki-laki dengan lebih dari seorang wanita dalam waktu yang sama. Lihat Soemiyati, Hukum Perkawinan Dalam Islam dan Undang-Undang Perkawinan (Yogyakarta: Liberty, 1986), him. 74

${ }^{34}$ Lihat Undang-Undang Nomor 1 Tahun 1974 Tentang Perkawinan.

${ }^{35}$ Lihat Peraturan Pemerintah Nomor 9 Tahun 1975 Tentang Pelaksanaan Undang-Undang Nomor 1 Tahun 1974 Tentang Perkawinan.

${ }^{36}$ Lihat Peraturan Pemerintah Nomor 10 Tahun 1983 Tentang Izin Perkawinan dan Perceraian Bagi Pegawai Negeri Sipil. 
Perkawinan dan Perceraian Bagi Pegawai Negeri Sipil, poligami diatur dalam Pasal I. ${ }^{37}$ Sedangkan dalam Kompilasi Hukum Islam, poligami diatur dalam Bab IX Pasal 55-59.

Dari beberapa dasar dan aturan yang telah dikemukakan dapat dipahami bahwa asas perkawinan dalam perundang-undangan Indonesia adalah monogami terbuka, tidak bersifat mutlak. ${ }^{38}$ Sebab, menurut Pasal 3 ayat (1) Undang-Undang Nomor 1 Tahun 1974 dikatakan bahwa seorang suami hanya boleh mempunyai seorang isteri begitu pula sebaliknya. Tetapi pada Pasal 3 ayat (2) Undang-Undang Nomor 1 Tahun 1974 dinyatakan bahwa pengadilan dapat memberi izin kepada seorang suami untuk beristeri lebih dari seorang apabila dikehendaki oleh pihak-pihak yang bersangkutan. Dengan adanya ayat (2) ini berarti Undang-Undang ini menganut asas monogami terbuka. Oleh karena itu tidak tertutup kemungkinan dalam keadaan tertentu seorang suami melakukan poligami yang tentunya dengan pengawasan pengadilan. ${ }^{39}$

Dalam hal seorang suami akan beristeri lebih dari seorang, maka ia wajib mengajukan permohonan kepada pengadilan di daerah tempat tinggalnya. Pengadilan dimaksud hanya memberi izin kepada suami yang ingin beristeri lebih dari seorang apabila cukup alasanalasannya. Alasan-alasan tersebut yaitu (a) isteri tidak dapat menjalankan kewajibannya sebagai isteri, (b) isteri mendapat cacat badan atau penyakit tidak dapat disembuhkan, dan (c) isteri tidak dapat melahirkan keturunan. ${ }^{40}$ Untuk memenuhi alasan-asalan ini, suami yang ingin berpoligami harus memenuhi syarat-syarat yaitu adanya persetujuan dari isteri/isteri-isteri, adanya kepastian bahwa suami mampu menjamin keperluan-keperluan hidup isteri-isteri dan anak-anak mereka, dan adanya jaminan bahwa suami akan berlaku adil terhadap isteri-isteri dan anak-anak mereka. ${ }^{41}$ Jika salah satu alasan terpenuhi, maka suami boleh melakukan poligami. ${ }^{42}$ Lalu dalam Peraturan Pemerintah yang dikhususkan bagi Pegawai Negeri Sipil, pada hakekatnya alasan dan persyaratan untuk berpoligami tetap substansinya sama dengan alasan-alasan yang telah dikemukakan, hanya mendapat tambahan dengan memperoleh izin terlebih dahulu dari Pejabat, ${ }^{43}$ yang kelihatannya sangat prosedural dan terlalu panjang. Syarat-syarat dan alasan-alasan tersebut boleh dikatakan sulit untuk dipenuhi oleh mereka yang ingin melakukan poligami.

Pernikahan siri Moerdiono dan Machica telah melanggar syarat-syarat dan alasan yang ditentukan oleh perundang-undangan Indonesia. Padahal Moerdiono, selaku pejabat negara, sudah seharusnya lebih mengerti dan menjaga peraturan yang telah ada dan memberikan tauladan baik bagi masyarakat Indonesia, tetapi malah sebaliknya. Selain itu juga, tentunya Moerdiono mengetahui bahwa dalam perundang-undangan Indonesia, suatu pernikahan harus dicatatkan di pegawai pencatat nikah. ${ }^{44}$ Satu lagi pelanggaran hukum telah dilakukan oleh Moerdiono. Begitu juga Machica, seharusnya ia menyadari dan menjunjung tinggi aturan yang telah ditetapkan. Dengan demikian, Moerdiono dan Machica telah melakukan pelanggaran terhadap aturan yang berlaku.

${ }^{37}$ Lihat Peraturan Pemerintah Nomor 45 Tahun 1990 Tentang Perubahan Atas Peraturan Pemerintah Nomor 10 Tahun 1983 Tentang Izin Perkawinan dan Perceraian Bagi Pegawai Negeri Sipil.

39 Soemiyati, Hukum Perkawinan dalam Islam dan Undang-Undang Perkawinan, him. 77.

39 ibid.

40 Lihat Pasal 4 ayat (1) dan (2) Undang-Undang Nomor 1 Tahun 1974 Tentang Perkawinan; Lihat juga Pasal 41 Peraturan Pemerintah Nomor 9 Tahun 1975 Tentang Pelaksanaan Undang-Undang Nomor 1 Tahun 1974 Tentang Perkawinan.

41 Lihat Pasal 5 ayat (1) Undang-Undang Nomor 1 Tahun 1974 Tentang Perkawinan; Lihat juga Pasal 55 dan 58 ayat (1) Kompilasi Hukum Islam. Kemudian dalam Kompilasi Hukum Islam Pasal 58 ayat (2) terdapat syarat tambahan yaitu adanya persetujuan lisan isteri pada sidang Pengadilan Agama.

42 Hilman Hadikusuma, Hukum Perkawinan Indonesia Menurut Perundangan, Hukum Adat, Hukum Agama, him. 35.

43 Lihat Pasal 4 dan 5 Peraturan Pemerintah Nomor 10 Tahun 1983 Tentang Izin Perkawinan dan Perceraian Bagi Pegawai Negeri Sipil; Lihat juga Pasal l ayat (2) dan (3) Peraturan Pemerintah Nomor 45 Tahun 1990 Tentang Perubahan Atas Peraturan Pemerintah Nomor 10 Tahun 1983 Tentang Izin Perkawinan dan Perceraian Bagi Pegawai Negeri Sipil.

44 Lihat Pasal 2 ayat (2) Undang-Undang Nomor 1 Tahun 1974 Tentang Perkawinan. 
Mahkamah Konstitusi sebagai salah satu lembaga kehakiman di Indonesia, sudah sepantasnya menjaga berlakunya hukum dengan baik di negeri ini. Pelanggaran yang dilakukan oleh warga negara apalagi pejabat negarahendaknya diadilidengan pertimbangan yang baik demi tertegaknya hukum dengan baik pula. Mahkamah Konstitusi, melalui Putusan Mahkamah Konstitusi Nomor 46/PUU-VIII/2010 Tentang Status Anak Luar Nikah, telah menunjukkan ketidaktaatannya pada hukum dan aturan yang berlaku di Indonesia karena mengandung penafsiran bahwa Mahkamah Konstitusi, melalui putusan tersebut, telah mengesahkan atau paling tidak mempermudah praktik poligami dan perkawinan siri. Meski di satu sisi Mahkamah Konstitusi berupaya untuk melindungi anak melalui putusan tersebut, tetapi tetap tidak boleh melanggar hukum yang berlaku.

Akibat yang timbul dari hal yang demikian adalah bahwa Mahkamah Konstitusi melalui putusan tersebut telah membuat kegoncangan ${ }^{45}$ dan kerancuan hukum. Di antara dampak yang bisa dilihat adalah ketika pengadilan akan membuat putusan terhadap kasus seperti yang dialami Machica (pernikahan siri) atau kasus perzinaan. Dalam kasus Machica, pada tanggal 24 April 2013, Pengadilan Agama (PA) Jakarta Selatan menolak permohonan Machica. ${ }^{46}$ Alasannya adalah pernikahan Machica dengan Moerdiono merupakan pernikahan siri yang tidak diakui oleh hukum yang berlaku di Indonesia. Meskipun Putusan Mahkamah Konstitusi tersebut sudah bisa menjadi sumber kekuatan hukum bagi Machica, namun pada praktiknya tetap tidak bisa diterima. Dengan kata lain, sebenarnya Putusan Mahkamah Konstitusi tersebut tidak bisa diberlakukan, juga tidak diperlukan, karena bertentangan dengan Undang-Undang Perkawinan yang berlaku. Itu sebabnya kehadiran putusan tersebut hanya menimbulkan kerancuan hukum.

\section{Tinjauan Normatif}

Yang dimaksud tinjauan normatif di sini adalah tinjauan dari segi Hukum Islam. Hasil analișis berdasarkan pendekatan normatif ini adalah sebagai berikut.

a. Pengabaian maqashid asy-syari'ah

Hukum Islam hadir dengan tujuan yang mulia karena ia bersumber dari titah Allah swt. Tujuan pemberlakuan Hukum Islam ini dikenal dengan istilah maqashid asy-syari'ah. Ada lima hal yang menjadi tujuan pemberlakuan Hukum Islam (maqashid asy-syari'ah), yaitu dalam rangka menjaga agama, jiwa, akal, harta, dan keturunan. Kelima hal ini disebut dengan al-kulliyyat al-khamsah. ${ }^{47}$

Sebagai upaya menjaga dan memelihara kemurnian keturunan, yang berkaitan erat dengan Putusan Mahkamah Konstitusi yang dikaji dalam penelitian ini, setidaknya ada tiga cara yang disepakati oleh fuqaha' (ulama fikih) untuk menetapkan nasab kepada orangtuanya, terkhusus kepada ayahnya. Cara-cara tersebut adalah dengan pernikahan sah atau fasid, pengakuan atas nasab anak, dan pembuktian. Ketiga cara ini merupakan cara yang disepakati oleh fuqaha'. Berikut akan dijelaskan cara-cara yang dimaksud.

\section{b. Pernikahan sah atau fasid}

Fuqaha' sepakat menyatakan bahwa pernikahan yang sah atau fasid merupakan salah satu cara atau dasar yang sangat kuat dan dianggap sah untuk menetapkan nasab seorang anak kepada kedua orang tuanya meskipun pernikahan dan kelahiran anak itu

45 Dadan Muttaqien, "Keputusan Mahkamah Konstitusi Republik Indonesia No. 46/PUU-VIII/2010 Tanggal 13 Februari 2012 Tentang Pengujian Terhadap Pasal 2 Ayat (2) dan Pasal 43 Ayat (1) Undang-Undang No. 1 Tahun 1974 Tentang Perkawinan dalam Perspektif Hukum Perdata Indonesia", him. 4.

${ }^{46}$ Berita di acara infotainment "Was-Was" dalam http://www.voutube.com/watch?v=GWgsX29kNis. diakses 4 Mei 2013.

47 Abu> Ish\{a>q asy-Sya>t\}ibi>, al-Muwa $>$ faqa $>t$ fi $>$ Us\} $u l$ asy-Syari> 'ah, vol. II (Mesir: Da>r al-Fikr, $1341 \mathrm{H}$.), hlm. 5. 
tidak didaftarkan secara resmi pada instansi terkait. ${ }^{48}$ Ini memberi arti bahwa hubungan nasab anak yang dilahirkan oleh seorang wanita tetap dapat diakui dan ditetapkan dengan syarat terjadinya pernikahan, baik pernikahan itu sah, fasid, atau berupa menikah secara adat masyarakat tertentu (pernikahan yang dianggap terlaksana dengan akad-akad khusus).

c. Pengakuan terhadap Anak

Jika seorang laki-laki mengakui bahwa seorang anak kecil (seseorang) adalah anaknya atau sebaliknya seorang anak kecil (seseorang) mengakui seorang laki-laki adalah ayahnya, maka pengakuan itu dapat dibenarkan dengan syarat-syarat:49

1) Anak yang menyampaikan pengakuan itu tidak jelas nasabnya. Apabila ayahnya diketahui, pengakuan tersebut menjadi batal.

2) Pengakuan itu diterima secara akal (logis). Sebagai contoh, usia ayah dan anak yang ada dalam pengakuan tersebut terpaut jarak yang diterima secara akal. Jika ada dua orang yang mengaku menjadi ayah dari seorang anak, maka hakim harus meneliti lebih jauh siapa yang berhak terhadap seorang anak yang dimaksud.

3) Anak tersebut telah baligh dan berakal (menurut mayoritas ulama) dan mumayyiz (menurut ulama mazhab Hanafi). Tetapi, syarat ini tidak diterima oleh ulama Maliki karena, menurut mereka, nasab merupakan hak anak, bukan ayah.

4) Laki-laki yang mengakui nasab anak tersebut harus menegaskan bahwa ia bukan anak dari hasil zina karena zina tidak bisa menjadi dasar penetapan nasab anak.

Apabila syarat-syarat tersebut telah terpenuhi, maka pengakuan nasab oleh seorang ayah adalah sah dan anak tersebut berhak mendapatkan nafkah, pendidikan selayaknya, dan harta warisan dari ayahnya tersebut. Ketika seseorang telah mengakui anak tersebut sebagai anaknya, pengakuannya tidak bisa dan tidak boleh dicabut kembali karena nasab tidak bisa dibatalkan..$^{50}$

d. Pembuktian

Alat bukti dalam menentukan nasab adalah kesaksian. Status kesaksian lebih kuat daripada pengakuan. Sebabnya kesaksian sebagai alat bukti selalu melibatkan orang lain sebagai penguat. ${ }^{51}$ Para ulama fikih berbeda pendapat tentang jumlah saksi dalam perkara ini. Menurut Imam Abu Hanifah dan Muhammad bin Hasan saksi harus berjumlah empat orang yang terdiri dari dua laki-laki dan dua perempuan. Menurut mazhab Maliki kesaksian dua orang laki-laki sudah dianggap cukup. Sedangkan menurut mazhab Syafi'i dan Hanbali serta Abu Yusuf kesaksian harus diungkapkan oleh semua ahli waris. ${ }^{52}$

Semua cara di atas adalah demi terjaganya salah satu tujuan pemberlakuan Hukum Islam (maqashid asy-syari'ah) yaitu menjaga keturunan.

Penelaahan terhadap Putusan Mahkamah Konstitusi Nomor 46/PUU-VIII/2010 memperlihatkan hasil yang bertolak belakang dengan maqashid asy-syari'ah. Putusan Mahkamah Konstitusi Nomor 46/PUU-VIII/2010 tersebut bisa mengandung penafsiran yang tidak sesuai dengan maqashid asy-syariah karena bisa dipahami adanya pelegalan

\footnotetext{
48 Wahbah az-Zuhaili>, al-Fiqh al-Isla>mi> wa Adillatuh, Jilid 7, cet. ke-1 (Damaskus: Da>r al-Fikr, 1987), hlm. 690.

49 Lihat ibid., hlm. 690-691; Lihat juga M. Nurul Irfan, Nasab \& Status Anak dalam Hukum Islam (Jakarta: Amzah, 2012), him. 125-128.

50 Wahbah az-Zuhaili, al-Fiqh al-Islami wa Adillatuh, hlm. 692.

51 Muhammad Yusuf Musa, an-Nasab wa Asaruh (Kairo: Da>r al-Ma'rifah, t.th.), hlm. 32.

52 Wahbah az-Zuhaili, al-Fiqh al-Islami wa Adillatuh, hlm. 695.
} 
perzinaan. ${ }^{53}$ Ini dikarenakan bahwa istilah anak di luar nikah bisa mengandung pengertian anak yang terlahir di luar nikah yang dicatatkan oleh pegawai pencatat nikah (anak dari nikah siri) dan/atau anak yang lahir akibat perbuatan zina. Oleh karena itu, Putusan Mahkamah Konstitusi ini telah menyalahi ketentuan Hukum Islam yang merupakan landasan utama bagi umat Islam.

Untuk konteks saat ini, jika terjadi sengketa dalam penetapan nasab anak, tampaknya penetapan nasab anak tersebut bisa ditempuh melalui dunia kedokteran dengan cara tes darah atau bahkan tes DNA. Cara ini merupakan pengembangan dari cara pengakuan dan pembuktian sebagai akibat perkembangan ilmu pengetahuan dan teknologi. Walaupun demikian, tidak semua nasab anak bisa ditetapkan dan dinyatakan sah dengan cara ini jika terdapat kesesuaian. ${ }^{54}$ Nasab anak dengan cara ini hanya bisa ditetapkan dan dinyatakan sah jika terjadi dalam kasus kehamilan akibat pernikahan yang sah secara Hukum Islam. Dalam kasus perkawinan siri, hendaknya ada saksi-saksi yang benar-benar mengetahui bahwa pernikahan itu benar-benar terjadi. Namun, hal ini bisa menjadi sulit untuk dilakukan, seperti pada kasus Machica. Untuk pembuktian melalui tes DNA, apakah makam Moerdiono harus dibongkar untuk mengambil sample DNAnya? Tentu hal ini bukanlah hal yang mudah dan disetujui oleh banyak pihak. Sebenarnya jika ada bukti-bukti berupa saksi, dokumentasi dalam bentuk foto atau video, serta keterangan-keterangan lain atas pernikahan (siri) seseorang, tentunya itu dapat diterima. Di sinilah letak pentingnya pencatatan perkawinan, yaitu agar perkawinan memiliki kekuatan di depan hukum.

Dalam kasus kehamilan akibat perzinaan, nasab anak tidak bisa ditetapkan dan tidak bisa dianggap sah dengan cara pembuktian dengan ilmu pengetahuan dan teknologi mutakhir. Bagaimanapun juga, anak di luar nikah (anak zina) tidak bisa mendapatkan hubungan nasab terhadap ayah biologisnya walaupun telah terbukti secara ilmu pengetahuan dan teknologi bahwa itu adalah anaknya (ayah biologis). Anak di luar nikah (anak zina) hanya memiliki hubungan nasab dengan ibunya. Dalam sebuah hadis yang diriwayatkan oleh Imam Muslim disebutkan bahwa nasab anak merupakan milik hubungan pernikahan yang sah dan dinasabkan kepada suami.

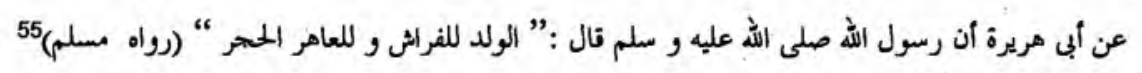

"Anak itu milik yang mempunyai tempat tidur yang sah (suami), sedangkan bagi pezina adalah hukum rajam".

c. Memasuki Ranah Syar'i

Hukum Islam, sebagaimana telah dijelaskan pada Bab II, mengandung dua pengertian. Pertama, ketentuan-ketentuan (hukum) Islam yang jelas dan rinci seperti masalah ibadah, pernikahan, ketentuan warisan, dan seterusnya. Bagian ini merupakan wilayah syari'ah. Kedua, ketentuan-ketentuan (hukum) Islam yang diformulasikan melalui penguraian akal. Bagian ini merupakan wilayah fiqh. ${ }^{56}$

Permasalahan yang menjadi fokus dalam kajian ini adalah Putusan Mahkamah Konstitusi mengenai permasalahan hubungan perdata dan nasab anak luar nikah terhadap

${ }^{53}$ Lihat respon dari Majelis Ulama Indonesia menyikapi Putusan Mahkamah Konstitusi tersebut "MUI Nilai Keputusan MK Soal Status Anak di Luar Nikah Overdosis", dalam http://news.detik.com/read/2012/03/13/164310/1866192/10/mui-nilai-keputusanmk-soal-status-anak-di-luar-nikah-overdosis?9911012, dlakses 11 Maret 2013; Lihat juga "Fatwa MUI Tentang Kedudukan Anak Hasil Zina dan Perlakuan Terhadapnya", dalam http://www.voa-islam.com/news/indonesiana/2012/03/22/18307/fatwamui-tentana-kedudukan-anak-hasil-zina-dan-perlakuan-terhadaonval.

${ }^{54}$ M. Nurul Irfan, Nasab \& Status Anak dalam Hukum Islam, hlm. 132-133.

${ }^{55}$ Yahya Syarf an-Nawawi ad-Dimasyqi asy-Syafi'i, Sahih Muslim bi Syarh an-Nawawi, cet. ke-4, vol. X (Beirut: Dar alKutub al-'Ilmiyyah, 2010), hlm. 33.

56 Yusuf al-Qaradawi, Madkhal li Dirasah asy-Syari'ah al-Islamiyyah (Kairo: Maktabah Wahbah, 2001), hlm. 22. 
ayah biologisnya, bahkan terhadap keluarga ayahnya tersebut. Permasalahan ini berkaitan erat dengan masalah pernikahan. Persoalan nikah merupakan persoalan yang telah diatur dengan jelas dan rinci dalam Hukum Islam.

Selain bisa dipahami sebagai pelegalan perzinaan, sebagaimana disebutkan di atas, Putusan Mahkamah Konstitusi Nomor 46/PUU-VIII/2010 juga mengandung unsur pelanggaran syar'i lainnya yaitu membuat suatu hukum baru atas hubungan perdata yang telah digariskan oleh Islam. Dalam Amar Putusan Mahkamah Konstitusi Nomor 46/PUUVIII/2010 dinyatakan bahwa "...yang dapat dibuktikan berdasarkan ilmu pengetahuan dan teknologi dan/atau alat bukti lain...". Ini memberi arti bahwa dengan terpenuhinya pembuktian tersebut hubungan perdata seorang anak dapat terhubung kepada kedua orang tua biologisnya bahkan keluarga kedua orang tua biologisnya. Perlu diketahui bahwa hubungan perdata yang dimaksud dalam Hukum Islam (hubungan perdata Islam) adalah terkait dengan nasab, nafkah, wali, dan waris ${ }^{57}$ Dalam ketentuan Hukum Islam, hubungan perdata ini hanya bisa terbentuk melalui pernikahan yang sah. Dengan memberikan syarat pembuktian ilmu pengetahuan dan teknologi mutakhir, Mahkamah Konstitusi telah, walaupun mungkin secara tidak langsung, membuat syarat baru atas sahnya suatu nasab. Hal ini tentunya juga menyiratkan makna membuat hukum baru tentang sahnya pernikahan ${ }^{58}$ Ini tentu telah melampaui kewenangan Dewan Perwakilan Rakyat bahkan Tuhan sekalipun. ${ }^{59}$

\section{d. Keluar dari Batas Penggunaan Ra'yu (ljtihad)}

Pada prinsipnya ijtihad (ra'yu) ${ }^{60}$ digunakan dalam menetapkan suatu hukum jika tidak terdapat aturan-aturan secara harfiah tentangnya. Begitu pula, dalam keadaan tertentu, ijtihad dapat digunakan terhadap hal-hal yang sudah diatur oleh nas) tetapi dalam pengaturannya tidak secara pasti. Sebelumnya telah dikemukakan sebuah nash (Hadis Nabi saw.) yang menerangkan secara jelas tentang penetapan nasab seorang anak. Meskipun Putusan Mahkamah Konstitusi Nomor 46/PUU-VIII/2010 bertujuan mencapai kemaslahatan dalam melindungi anak, tetap tidak bisa dianggap sebagai suatu ijthad yang dibolehkan karena telah ada nas\} secara tegas mengatur masalah terkait. Mengenai hal ini ada kaidah fikih yang menyatakan:

"Tidak ada peluang untuk berijtihad pada tempat yang ada nas\}"

Berdasarkan hasil analisis dari tinjauan normatif ini, maka Putusan Mahkamah Konstitusi Nomor 46/PUU-VIII/2010 Tentang Status Anak Luar Nikah telah melanggar ketentuan-ketentuan yang telah diatur oleh Hukum Islam. Karena Hukum Islam bersumber dari Allah swt.,sebagai Law Giver, Putusan Mahkamah Konstitusi tersebut tidak bisa mengubah aturan dan ketentuan yang telah ditetapkan dan diatur oleh Hukum Islam.

Mungkin ada pertanyaan yang lahir terkait antara ketaatan kepada Allah dan pada pemimpin. Bagaimanakah posisi masyarakat muslim Indonesia sebagai warga negara? Bukankah Islam juga memerintahkan untuk mentaati pemimpin selain mentaati Allah dan RasulNya? Mahkamah Konstitusi termasuk dalam jajaran pemimpin tersebut.

57 Ini dikemukakan oleh Ketua Majelis Ulama Indonesia, Ma'ruf Amin, dalam "Kata Pengantar" untuk M. Nurul Irfan, Nasab \& Status Anak dalam Hukum Islam, him. vl.

58 Dadan Muttaqien, "Keputusan Mahkamah Konstitusi Republik Indonesia No. 46/PUU-VIII/2010 Tanggal 13 Februari 2012 Tentang Pengujian Terhadap Pasal 2 Ayat (2) dan Pasal 43 Ayat (1) Undang-Undang No. 1 Tahun 1974 Tentang Perkawinan dalam Perspektif Hukum Perdata Indonesia", hlm. 3.

59 Ibid.

60 Penjelasan mengenai ijtihad telah diuraikan dalam Bab II pada bagian Sumber Hukum Islam.

61 Ali Ahmad an-Nadwa, al-Qawa'id al-Fiqhiyyah: Mafhumuha, nasy'atuha, tat\}awwuruha, dirasatu muallafatiha, adillatuha, muhimmatuha, tatbiqatuha, cet. ke-5 (Damaskus: Da>r al-Qalam, 2000), hlm. 180. 
Hukum Islam adalah hukum yang berasal dari Allah swt., Oleh karena itu, asas Hukum Islam adalah ketuhanan. Namun demikian, sejarah pemerintahan Islam menunjukkan bahwa kepala negara atau pemerintahan mempunyai wewenang untuk membuat peraturan perundang-undangan secara langsung terlebih jika kemaslahatan umum mengharuskan demikian. ${ }^{62}$

Menurut Abu al-A'la al-Maududi, sebagaimana yang dikutip oleh Dede Rosyada, dalam sistem pemerintahan Islam tidak hanya terdapat kedaulatan Tuhan, tetapi dalam sistem tersebut terdapat pula kedaulatan rakyat yang disalurkan melalui parlemen. ${ }^{63}$ Kewenangan tersebut dinyatakan Allah swt. dalam Q.S. an-Nisa' (4): 59. Tetapi, kewenangan yang diemban oleh pemerintah ini hanya wajib ditaati sepanjang peraturan perundang-undangan itu tidak menyalahi hukum Allah swt. Hal ini dikarenakan otoritas, independensi, dan kekuatan tertinggi yang dimiliki oleh pemerintah merupakan pendelegasian dari Allah swt. ${ }^{64}$ Dengan demikian, umat Islam tidak boleh patuh pada peraturan perundang-undangan yang bertentangan dengan ketentuan yang telah diatur oleh Hukum Islam. Karena Putusan Mahkamah Konstitusi Nomor 46/PUU-VIII/2010 itu bertentangan dengan Hukum Islam, maka ia tidak boleh dipatuhi.

\section{Tinjauan Sosiologis}

Maksud tinjauan sosiologis di sini adalah mendekati masalah dengan melihat hubungan dan pengaruh timbal balik antara aneka macam gejala-gejala sosial. ${ }^{65}$ Dalam penelitian ini, hubungan dan pengaruh timbal balik yang dimaksud adalah hubungan dan pengaruh timbal balik antara hukum, yaitu Putusan Mahkamah Konstitusi Nomor 46/PUU-VIII/2010, dan gerak atau respon masyarakat.

Kehadiran Putusan Mahkamah Konstitusi Nomor 46/PUU-VIII/2010 telah melahirkan respon yang beragam ${ }^{66}$ respon-respon kontroversial yang melahirkan polemik yang berkepanjangan. Dalam waktu belakangan ini, Putusan Mahkamah Konstitusi tersebut masih banyak mendapat pertentangan serta masih hangat dibicarakan dan didiskusikan. ${ }^{67}$

Putusan Mahkamah Konstitusi Nomor 46/PUU-VIII/2010 oleh sebagian kalangan dinilai sebagai sebuah aturan yang melindungi hak-hak anak. ${ }^{68}$ Pernyataan demikian memang benar adanya. Dengan adanya putusan tersebut, kepentingan dan hak-hak anak yang seharusnya ia dapatkan dari ayah biologisnya bisa ia terima. Tidak ada seorang anak pun yang dilahirkan di muka bumi harus dipersalahkan dan diperlakukan diskriminatif karena ulah atau cara pernikahan kedua tuanya.

Dari berbagai respon yang bermunculan, respon yang cukup berpengaruh adalah respon dari Majelis Ulama Indonesia (MUI) karena ia merupakan lembaga yang memiliki pijakan dasar yang kuat sekaligus sebagai representasi umat Islam Indonesia. Tepatnya tertanggal 10 Maret $2010 \mathrm{MUI}$ mengeluarkan fatwa untuk mensikapi Putusan Mahkamah Konstitusi Nomor 46/PUU-VIII/2010. Fatwa yang dimaksud adalah Fatwa majelis Ulama Indonesia Nomor 11 Tahun 2012 Tentang Kedudukan Anak Hasil Zina dan Perlakuan Terhadapnya. Di dalam fatwanya pada bagian ketentuan hukum, Majelis

${ }^{62}$ Sobhi Mahmassani, Filsafat Hukum dalam Islam, terj. Ahmad Sudjono, cet. ke-3 (Bandung: Al-Ma'arif, t.t.), him. 249.

${ }^{63}$ Dede Rosyada, Hukum Islam dan Pranata Sosial, cet. ke-3 (Jakarta: PT RajaGrafindo Persada, 1995), him. 179.

${ }_{64}$ Muhammad Muslehuddin, Filsafat Hukum Islam dan Pemikiran Orientalis: Studi Perbandingan Sistem Hukum Islam, terj. Yudian Wahyudi Asmin, cet. ke-2 (Yogyakarta: Tiara Wacana Yogya, 1997), hlm. 45.

65 Pitirim Sorokim sebagaimana dikutip oleh Soerjono Soekanto, Sosiologi: Suatu Pengantar, Edisi Baru Keempat, cet. ke-27 (Jakarta: PT RajaGrafindo Persada, 1999), him. 20.

${ }_{66}$ Mengenai respon yang bermunculan, teiah dicontohkan dalam Bab III dalam sub-judul "Sejarah Putusan Mahkamah Konstitusi Nomor 46/PUU-VIII/2010".

${ }_{67}$ Sebagai contoh, pada acara "MoU antara Komisi Yudisial (KY) dengan Universitas Islam Negeri Sunan Kalijaga" tanggal 28 Maret 2013 terdapat salah satu agenda bedah buku Legislasi Hukum Perkawinan di Indonesia: Pro-Kontra Pembentukannya Hingga Putusan Mahkamah Konstitusi (Jakarta: Kencana, 2013) karya Taufiqurrohman Syahuri, salah seorang anggota Komisi Yudisial. Penulis hadir dalam acara ini. Dalam buku ini dimuat uraian tentang Putusan Mahkamah Konstitusi Nomor 46/ PUU-VIII/. Dalam agenda bedah buku ini masih terlihat diskusi yang hangat antara pro-kontra terhadap Putusan Mahkamah Konstitusi Nomor 46/PUU-VIII/2010 tersebut.

${ }_{68}$ Sebagai salah satu contoh adalah pernyataan dari M. Nurul Irfan selaku saksi ahli pada perkara Machica Mochtar tersebut. Lihat M. Nurul Irfan, Nasab \& Status Anak dalam Hukum Islam, him. 171. 
Ulama Indonesia memutuskan enam ketetapan. ${ }^{69}$ Pertama, anak hasil zina tidak mempunyai hubungan nasab, wali nikah, waris, dan nafkah dengan lelaki yang menyebabkan kelahirannya. Kedua, anak hasil zina hanya mempunyai hubungan nasab, waris, dan nafkah dengan ibunya dan keluarga ibunya. Ketiga, anak hasil zina tidak menanggung dosa perzinaan yang dilakukan oleh orang yang mengakibatkan kelahirannya. Keempat, pezina dikenakan hukuman hadd ${ }^{70}$ oleh pihak yang berwenang, untuk kepentingan menjaga keturunan yang sah (hifz an-nas/). Kelima, pemerintah berwenang menjatuhkan hukuman ta'zir ${ }^{71}$ terhadap laki-laki pezina yang mengakibatkan lahirnya anak dengan mewajibkannya untuk mencukupi kebutuhan hidup anak tersebut dan memberikan harta setelah ia meninggal melalui wasiyyah wajibah. Keenam, Hukuman ta'zir yang dimaksud bertujuan melindungi anak, bukan untuk mensahkan hubungan nasab antara anak tersebut dengan lelaki yang mengakibatkan kelahirannya.

Alasan utama hadirnya Fatwa Majelis Ulama Indonesia ini adalah bahwa Putusan Mahkamah Konstitusi tersebut menjadi kontroversial karena membuka peluang untuk dipahami adanya hubungan perdata antara anak yang dilahirkan dari hasil zina dengan lelaki yang mengakibatkan kelahirannya. Hubungan perdata dimaksud dalam Hukum Islam adalah terkait dengan nasab, waris, nafkah, dan wali. ${ }^{72}$ Sehingga Putusan Mahkamah Konstitusi tersebut dipahami dapat menjadi pintu dilegalkannya zina.

Dalam menanggapi berbagai respon atas putusan tersebut, terkhusus respon dari Majelis Ulama Indonesia, Mahkamah Konstitusi memberikan penjelasan atau pernyataan resmi bahwa Mahkamah Konstitusi tidak bermaksud melegalkan perzinaan.${ }^{73}$ Menurut Mahkamah Konstitusi, putusan tersebut tidak terkait sah atau tidaknya perkawinan, tetapi hanya untuk memberikan perlindungan hak keperdataan anak sehingga harus dipahami antara memberikan perlindungan terhadap anak dan persoalan perzinaan merupakan dua rezim hukum yang berbeda. ${ }^{74}$

Meskipun Mahkamah Konstitusi telah membuat pernyataan demikian, tetapi dalam putusan tersebut tetap bisa dipahami sebagai pelegalan zina. Sebabnya, kata "anak yang dilahirkan di luar perkawinan", sebagaimana yang tercantum dalam Putusan Mahkamah Konstitusi tersebut, bisa memiliki dua pengertian yaitu anak yang lahir akibat nikah siri (nikah di bawah tangan) dan anak yang lahir sebagai akibat perzinaan, seperti semen lavel (kumpul kebo) dan jenis-jenis kontak seksual dalam bentuk hubungan khusus yang lain. Karena inilah Majelis Ulama Indonesia sampai sekarang tidak mencabut fatwanya. Putusan Mahkamah Konstitusi tersebut muncul karena adanya kesalahan berpikir; ingin mendatangkan maslahat tetapi melanggar ketentuan syari'ah. ${ }^{75}$

Dalam Fatwa Majelis Ulama Indonesia tersebut ada hal penting yang diputuskan atau ditawarkan sebagai jalan keluar atas masalah status hukum anak zina. Soiusi tersebut adalah melalui kebijakan pemerintah dengan menetapkan ta'zir. Ada dua hal yang terkandung dalam ta'zir tersebut. Pertama, laki-laki yang mengakibatkan kelahiran anak di luar nikah tersebut harus menanggung kebutuhan hidup anak tersebut. Kedua, mewajibkannya memberikan harta tinggalan melalui wasiyyah wajibah.

Harus diakui bahwa nas\} yang terkait dengan syari'ah (Hukum Islam) walaupun ada yang bersifat pasti (qat'iyyah) tetapi lebih banyak bersifat perlu penggalian lebih dalam dan

${ }^{69}$ Lihat Fatwa Majelis Ulama Indonesia Nomor 11 Tahun 2012 tentang Kedudukan Anak Hasil Zina dan Perlakuan Terhadapnya.

70 Majelis Ulama Indonesia, dalam fatwanya ini pada bagian ketentuan umum, menjelaskan bahwa hadd adalah jenis hukuman atas tindak pidana yang bentuk dan kadarnya telah ditetapkan oleh nash. Pengertian ini senada dengan yang disebutkan oleh 'Abdul Qa>dir 'Audah bahwa hadd adalah hukuman yang kadarnya telah ditentukan oleh Allah swt. Lihat 'Abdul Qadir 'Audah, At-Tasyri' al-Jina'i al-Islami Muqaranan bi al-Qanun al-Wad\}' $i$, cet. ke-11, vol. 2 (Beirut: Mu'assasah arRisa>lah, 1992), him. 79.

71. Di dalam fatwanya ini pada bagian ketentuan umum, Majelis Ulama Indonesia menjelaskan bahwa yang ta 'zir adalah jenis hukuman tindak pidana yang bentuk dan kadarnya diserahkan kepada ulil amri (pihak yang berwenang menetapkan hukuman). 'Abdul Qa>dir 'Audah mengartikan la'zir sebagai penjatuhan hukuman (sebagai pelajaran) atas kesalahan yang tidak disyari'atkan hadd. Lihat 'Abdul Qa>dir 'Audah, At-Tasyri' al-Sina' $i$ al-Islami Muqaranan bi al-Qanun al-Wad\}' $i$, him. 126127.

72 Ma'ruf Amin, "Kata Pengantar" untuk M. Nurul Irfan, Nasab \& Status Anak dalam Hukum Islam, him. vi.

73 "Penjelasan Resmi MK: Kami Tidak Melegalkan Zina", dalam http://news. detik.com/read/2012/03/07/143010/1860 279/10/oenielasan-resmi-mk-kami-tidak-meleaalkan-zina?nd992203605, diakses 09 April 2013.

${ }^{74} \mathrm{lbid}$.

75 Ma'ruf Amin, "Kata Pengantar" untuk M. Nurul Irfan, Nasab \& Status Anak dalam Hukum Islam, him. vii. 
lebih jauh melalui ijtihad (zanniyyah). ${ }^{76}$ Dengan demikian, iimu fikih yang membahas tentang syari'ah ini cenderung dinamis, tidak statis. Solusi atau konsep yang dicetuskan oleh Majelis Ulama Indonesia ini merupakan bentuk dinamisasi pemikiran Hukum Islam di Indonesia. Solusi ini tampak lebih baik karena mendatangkan maslahah tanpa menabrak syari'ah.

\section{Kesimpulan}

Dari keseluruhan uraian pada bab-bab terdahulu dapat disimpulkan kesimpulan bahwa Hukum Islam merupakan aturan yang berasal dari agama Islam dan memiliki kekuatan yang besar serta posisi yang utama bagi umat Islam, termasuk umat Islam Indonesia. Sistem hukum di Indonesia juga menempatkan Hukum Islam pada posisi yang tinggi dan dijadikan landasan hukum bagi umat Islam Indonesia. Banyak aturan-aturan di Indonesia merupakan pengobjektifikasian dari aturan-aturan yang ditetapkan oleh Hukum Islam. Sementara itu, Putusan Mahkamah Konstitusi juga memiliki kekuatan hukum yang besar dan posisi yang penting dalam sistem ketatanegaraan Indonesia. Namun, jika dihadapkan dengan Hukum Islam, Putusan Mahkamah Konstitusi tidak bisa mengubah ketentuan-ketentuan dan aturanaturan yang telah ditetapkan dan diatur oleh Hukum Islam secara jelas. Dengan demikian, Putusan Mahkamah Konstitusi Nomor 46/PUU-VIII/2010 Tentang Status Anak Luar Nikah tidak memiliki kekuatan jika dihadapkan dengan Hukum Islam karena bertentangan dengan ketentuan yang telah ditetapkan dan diatur secara jelas oleh Hukum Islam.

\section{DAFTAR PUSTAKA}

Ali, Mohammad Daud, Hukum Islam: Pengantar IImu Hukum dan Tata Hukum Islam di Indonesia, Edisi V, cet. ke-5, Jakarta: Rajawali Pers, 1996.

Amal, Taufik Adnan, Islam dan Tantangan Modernitas: Studi Atas Pemikiran hukum Fazlur Rahman, Bandung: Mizan, 1990.

Amin, Ma'ruf, "MK seperti Tuhan", dalam http://news.detik.com/read/2012/03/20/182016/1872568/ 10/putuskan-nasib-anak-di-luar-nikah-mui-mk-seperti-tuhan, diakses 09 April 2013.

Anam, Khurul, "Status Anak dalam Putusan Mahkamah Konstitusi No. 46/ PU-U-VIII/2010 Perspektif Hukum Islam", Skripsi tidak diterbitkan, Yogyakarta: Fakultas Syariah dan Hukum UIN Sunan Kalijaga, 2012.

Anwar, Syamsul, "Islamic Jurisprudence of Christian-Muslim Relations", Al-Jami'ah Journal of Islamic Studies, No. 60, Tahun 1997.

, Studi Hukum Islam Kontemporer, Jakarta: RM Books, 2007.

Asnawi, al-, Nihayah as-Sul: Syarh Minhaj al-Wusul fi 'Ilm al-Usul, vol. I, Mesir: Matba'ah 'Ali Subaih wa Auladih, t.t.

Asshiddiqie, Jimly, dan Mustafa Fakhri, Mahkamah Konstitusi: Kompilasi Ketentuan Konstitusi, Undang-Undang dan Peraturan di 78 Negara, Jakarta: Pusat Studi Hukum Tata Negara Fakultas Hukum UI, 2003.

Asshiddiqie, Jimly, "Mahkamah Konstitusi dalam Sistem Ketatanegaraan Republik Indonesia", makalah disampaikan pada Pendidikan Sespati dan Sespim Polri, Bandung, 19 April 2008.

\footnotetext{
${ }^{76}$ Pembahasan mengenai hal ini telah diuraikan dalam Bab III ketika menjelaskan tentang ijtihad sebagai sumber Hukum Islam.
} 
Putusan Mahkamah Konstitusi Tentang Status Anak ... Dadan Muttaqien \& M. Arif Zuhri , et.al., Menjaga Denyut Konstitusi: Refleksi Satu Tahun Mahkamah Konstitusi, Jakarta: Konstitusi Press, 2004.

. "Sejarah Constitusional Review dan Gagasan Pembentukan Mahkamah Konstitusi", dalam http://iim/yschool.com/read/analisis/276/sejarah-constitutional-review-qaaasanpembentukan-mk/ diakses 31 Maret 2013.

'Asymawi, Muhammad Sa'id-al, "Fikih Islam", dalam Johannes deb Heijer dan Syamsul Anwar (ed.), Islam, Negara dan Hukum, terj. Syamsul Anwar, Jakarta: INIS, 1993.

'Atiyyah, Abu Muhammad 'Abd al-Haqq ibn Galib ibn, al-Muharrar al-Wajiz fi Tafsir al-Kitab al'Aziz, vol. I, Beirut: Dar al-Kutub al-'Ilmiyyah, 1993.

'Audah, 'Abdul Qadir, At-Tasyri' al-Jina'i al-Islami Muqaranan bi al-Qanun al-Wad'i, cet. ke-11, vol. 2, Beirut: Mu'assasah ar-Risalah, 1992.

Coulson, N. J., A History of Islamic Law, Edinburgh: Edinburgh University Press, 1964.

Dahlan, Moh., Abdullah Ahmed an-Na'im: Epistemologi Hukum Islam, Yogyakarta: Pustaka Pelajar, 2009.

Departemen Agama Republik Indonesia, al-Qur'an dan Terjemahnya, Surakarta: Media Insani Publishing, t.th.

Fathurrahman Djamil, Filsafat Hukum Islam Bagian Pertama, Jakarta: Logos, 1997.

"Fatwa MUI Tentang Kedudukan Anak Hasil Zina dan Perlakuan Terhadapnya", dalamhttp:// www.voaislam.com/news/indonesiana/2012/03/22/18307/fatwa-mui-tentana-kedudukananak-hasil-zina-dan-perlakuan-terhadapnval; diakses 11 Maret 2013.

Gazzali, Abu Hamid al-, al-Mustasfa min 'llm al-Usul, Kairo: Syirkah at-Tiba'ah al-Fanniyyah al-Muttahidah, 1970.

Hadikusuma, Hilman, Hukum Perkawinan Indonesia menurut Perundangan, Hukum Adat, Hukum Agama, cet. I, Bandung: Mandar Maju, 1990.

Halim, Ahmad Canggih Ghulam, "Kedudukan Anak Hasil Pernikahan yang Tidak Sah Menurut Putusan Mahkamah Konstitusi dan Fatwa Majelis Ulama Indonesia", Skripsi tidak diterbitkan, Yogyakarta: Fakultas Syariah dan Hukum UIN Sunan Kalijaga, 2012.

Hamidullah, Muhammad et.al., Fikih Islam dan Hukum Romawi, terj. M. Ali Muhammad dan Rusjdi Ali Muhammad, Yogyakarta: Gama Media, 2003.

Harahap, M. Yahya, Hukum Acara Perdata tentang Gugatan, Persidangan, Penyitaan, Pembuktian, dan Putusan Pengadilan, Jakarta: Sinar Grafika, 2008.

Hasan, Ahmad, The Early Development of Islamic Law, New Delhi: Adam Publishers \& Distributors, 1994.

Hayyan, Muhammad ibn Yusuf Abu, Tafsir al-Bahr al-Muhit, vol. I, Beirut: Dar al-Kutub al'Ilmiyyah, 1993.

Hazairin, Demokrasi Pancasila, Jakarta: Bina Aksara, 1985. 
UNISIA, Vol. XXXV No. 78 Januari 2013

Huijbers , Theo, Filsafat Hukum dalam Lintasan Sejarah (Yogyakarta: Kanisius, 1995.

Hurgronje, C. Snouck, Islam di Hindia Belanda, cet. ke-2, terj. S. Gunawan, Jakarta: Bhratara Karya Aksara, 1983.

Irfan, M. Nurul, Nasab \& Status Anak dalam Hukum Islam, Jakarta: Amzah, 2012.

Jaya, Asafri, Konsep Maqashid Syari'ah Menurut al-Syathibi, Jakarta: PT RajaGrafindo Persada, 1996.

Khallaf, Abdul Wahhab, 'IIm Usul al-Figh, Kairo: Dar al-Qalam li at-Tiba'ah wa an-Nasyr wa at-Tauzi', 1978.

,'IIm Usul al-Fiqh, cet. ke-12, t.t.: Dar al-'Ilm, 1978.

Latif, Abdul, et.al., Buku Ajar Hukum Acara Mahkamah Konstitusi, Yogyakarta: Kreasi Total Media, 2009.

, Fungsi Mahkamah Kontitusi: Upaya Mewujudkan Negara Hukum Demokrasi, cet. ke2, Yogyakarta: Kreasi Total Media, 2009.

Lubis, Solly, Hukum Tata Negara, Bandung: Mandar Maju, 2008.

Mahfud MD, Moh., Membangun Politik Hukum, Menegakkan Konstitusi, cet. ke-2, Jakarta: PT RajaGrafindo Persada, 2011.

, Perdebatan Hukum Tata Negara Pasca Amandemen Konstitusi, cet. ke-2, Jakarta: PT RajaGrafindo Persada, 2011.

Mahmassani, Sobhi, Filsafat Hukum dalam Islam, terj. Ahmad Sudjono, cet. ke-3, Bandung: Al-Ma'arif, t.t.

Manzur, Jamaluddin Abi al-Fadl Muhammad ibn Makram ibn, Lisan al-'Arab, vol. X, Mesir: adDar al-Misriyyah li at-Ta'lif wa at-Tarjamah, t.t.

Martono, Nanang, Metode Penelitian Kuantitatif: Analisis /si dan Analisis Data Sekunder, Jakarta: RajaGrafindo Persada, 2011.

Mas'ud , Muhammad Khalid, Hukum Islam dan Perubahan Sosial, alih bahasa Yudian W. Asmin, cet. 1, Surabaya: Al-Ikhlas, 1995.

Meyrin, "Tinjauan Hukum Dampak Berlakunya Putusan Mahkamah Konstitusi Republik Indonesia Nomor 46/PUU-VIII/2010 Tentang Anak yang Lahir Di Luar Perkawinan Terhadap Akta Pengakuan Anak dan Surat Keterangan Hak Waris yang Dibuat oleh Notaris", Tesis, tidak diterbitkan, Depok: Fakultas Hukum Program Magister Kenotariatan, 2012.

"MUI Dukung MK, Ayah Bertanggung Jawab Atas Anak di Luar Nikah" dalamhttp://news. detik. com/read/2012/02/17/161029/1845303/10/mui-dukuna-mk-avah-bertanaquna-jawabatas-anak-di-luar-nikah?nd992203605, diakses 11 Maret 2013.

"MUI : Putusan MK Soal Status Anak di Luar Nikah Melampaui Batas", dalam http://www. islamedia.web.id/2012/03/mui-putusan-mk-soal-status-anak-di-luar.html, diakses 12 Februari 2013. 
Putusan Mahkamah Konstitusi Tentang Status Anak ... Dadan Muttaqien \& M. Arif Zuhri

"MUI: Putusan MK Soal Status Anak di Luar Nikah Melampaui Batas" dalam http://mvquran. ora/forum/index.pho/topic.75964. msa2146705.html?PHPSESSID=vpef0i8k43i82rabcnh ah9nik4\#msa2146705, diakses 11 Maret 2013.

"MUI Niiai Keputusan MK Soal Status Anak di Luar Nikah Overdosis, dalam http://news.detik. com/read/2012/03/13/164310/1866192/10/mui-nilai-keputusan-mk-soal-status-anak-diluar-nikah-overdosis?9911012, diakses 11 Maret 2013.

Munawwir, Ahmad Warson, Kamus Al-Munawwir Arab-Indonesia Terlengkap Edisi Kedua, cet. ke-14, Surabaya: Pustaka Progressif, 1997.

Musa, Muhammad Yusuf, an-Nasab wa Aslaruh, Kairo: Dar al-Ma'rifah, t.th.

, Tarikh al-Fiqh al-Islami, Mesir: Dar al-Kitab al-'Arabi, 1958.

Muslehuddin, Muhammad, Filsafat Hukum Islam dan Pemikiran Orientalis: Studi Perbandingan Sistem Hukum Islam, terj. Yudian Wahyudi Asmin, cet. ke-2, Yogyakarta: Tiara Wacana Yogya, 1997.

Muttaqien, Dadan, Dasar-Dasar Hukum Acara Perdata, Yogyakarta: Insania Cita Press, 2006.

, "Keputusan Mahkamah Konstitusi Republik Indonesia No. 46/PUU-VIII/2010 Tanggal 13 Februari 2012 Tentang Pengujian Terhadap Pasal 2 Ayat (2) dan Pasal 43 Ayat (1) Undang-Undang No. 1 Tahun 1974 Tentang Perkawinan dalam Perspektif Hukum Perdata Indonesia", Makalah tidak diterbitkan, disampaikan pada seminar regional 22 Maret 2012 yang diadakan oleh Fakultas IImu Agama Islam (FIAI) Universitas Islam Indonesia (UII) Yogyakarta dalam mensikapi Putusan Mahkamah Konstitusi No. 46/PUU-IX/2011 tentang Tanggung Jawab Ayah Terhadap Anak Di Luar Nikah.

MZ, Labib, Pembelaan Umat Muhammad, Surabaya: Bintang Pelajar, 1986.

Nadwa, Ali Ahmad an-, al-Qawa'id al-Fighiyyah: Mafhumuha, nasy'atuha, tat\}awwuruha, dirasatu muallafatiha, adillatuha, muhimmatuha, tatbiqatuha, cet. ke-5, Damaskus: Dar al-Qalam, 2000.

Naim, Abdullah Ahmed an-, Toward an Islamic Reformation: Civil Liberties, Human Rights, and International Law, Syracuse: Syracuse University Press, 1990.

Nawawi, Yahya Syarf an-, Sahih Muslim bi Syarh an-Nawawi, cet. ke-4, vol. X, Beirut: Dar alKutub al-'llmiyyah, 2010.

"Penjelasan Resmi MK: Kami Tidak Melegalkan Zina", dalam http://news.detik.com/re ad/2012/03/07/143010/1860279/10/penielasan-resmi-mk-kami-tidak-meleaalkanzina?nd992203605, diakses 09 April 2013.

Praja, Juhaya S., Hukum Islam di Indonesia: Pemikiran dan Praktik, Bandung: P.T. Remaja Rosdakarya, 1991.

Putusan Mahkamah Konstitusi Nomor 46/ PUU-VIII/2010 Tentang Status Anak Luar Nikah.

Qaradawi, Yusuf al-, Madkhal li Dirasah asy-Syari'ah al-Islamiyyah, Kairo: Maktabah Wahbah, 2001. 
UNISIA, Vol. XXXV No. 78 Januari 2013

, Ijtihad dalam Syari'at Islam: Beberapa Pandangan Analitis tentang ljtihad Kontemporer,

terj. Achmad Syatori, Jakarta: Bulan Bintang, 1987.

Radjab, Dasril, Hukum Tata Negara Indonesia, Jakarta: PT. Rineka Cipta, 1994.

Rahman, Fazlur, Islam, Garden City: Anchor Books, 1968.

Ranuhandoko, I.P.M., Terminologi Hukum, Jakarta: Sinar Grafika, 2000.

Rosyada, Dede, Hukum Islam dan Pranata Sosial, cet. ke-3, Jakarta: PT RajaGrafindo Persada, 1995.

Schaht, Joseph, An Introduction to Islamic Law, Oxford: Clarendon Press, 1964.

, The Origins of Muhammad Jurisprudence, Oxford: Clarendon Press, 1950.

Shiddieqy, T. M. Hasbi ash-, Filsafat Hukum Islam, Jakarta: Bulan Bintang, 1975.

Siahaan, Maruarar, Hukum Acara Mahkamah Konstitusi Republik Indonesia, Edisi Kedua, Jakarta: Sinar Grafika, 2011.

Sofyan, Syafran, "Putusan Mahkamah Konstitusi Tentang Status Anak Luar Kawin", dalam http://www.iim/vschool.com/read/analisis/256/putusan-mahkamah-konstitusi-tentangstatus-anak-luar-kawin/, diakses 11 Maret 2013.

Syaltut, Mahmud, Al-Islam: 'Aqidah wa Syari'ah, cet. ke-3, Mesir.: Dar al-Qalam, 1966.

Syarifuddin, Amir, Pembaruan Pemikiran dalam Hukum Islam, Padang: Angkasa Raya, 1990.

, "Pengertian dan Sumber Hukum Islam" dalam Ismail Muhammad Syah et.al., Filsafat Hukum Islam, Jakarta: Bumi Aksara, 1992.

Singarimbun, Masri, dan Sofian Efendi (ed.), Metode Penelitian Survei, Jakarta: LP3ES, 1989.

Soekanto, Soerjono, Pengantar Penelitian Hukum, Jakarta: UI Press, 2006.

Soemiyati, Hukum Perkawinan Dalam Islam dan Undang-Undang Perkawinan, Yogyakarta: Liberty, 1986.

, Sosiologi: Suatu Pengantar, Edisi Baru Keempat, cet. ke-27, Jakarta: PT RajaGrafindo Persada, 1999.

Syahuri, Taufiqurrohman, Legislasi Hukum Perkawinan di Indonesia: Pro-Kontra Pembentukannya Hingga Putusan Mahkamah Konstitusi, Jakarta: Kencana, 2013.

Syatibi, Abu Ishaq asy-, al-Muwafaqat fi Usul asy-Syari'ah, vol. II, Mesir: Dar al-Fikr, $1341 \mathrm{H}$.

Tim Peneliti, Mekanisme Impeachment \& Hukum Acara Mahkamah Konstitusi, Jakarta: Pusat Penelitian dan Pengkajian Sekretariat Jenderal dan Kepaniteraan Mahkamah Konstitusi Republik Indonesia bekerja sama dengan Konrad-Adenauer-Stiftung, 2005.

Tim Penyusun, Hukum Acara Mahkamah Konstitusi, Jakarta: Sekretariat Jenderal dan Kepaniteraan Mahkamah Konstitusi Republik Indonesia bekerja sama dengan Asosiasi Pengajar Hukum Acara Mahkamah Konstitusi, 2010. 
Putusan Mahkamah Konstitusi Tentang Status Anak ... Dadan Muttaqien \& M. Arif Zuhri

Tim Penyusun, Kamus Besar Bahasa Indonesia Edisi III, cet. ke-1, Jakarta: Balai Pustaka, 2001.

Umam, Khairul, Ushul Fiqih, Bandung: Pustaka Setia, 2001.

Undang-Undang Dasar Negara Republik Indonesia Tahun 1945.

Undang-Undang Nomor 24 Tahun 2003 Tentang Mahkamah Konstitusi.

Usman, Suparman, Hukum Islam: Asas-Asas dan Pengantar Studi Hukum Islam dalam Tata Hukum Indonesia, Jakarta: Gaya Media Pratama, 2001.

Wasian, Abdullah, "Akibat Hukum Perkawinan Siri (Tidak Dicatatkan) terhadap Kedudukan Istri, Anak, dan Harta Kekayaannya Ditinjau dari Hukum Islam dan Undang-Undang Perkawinan", Tesis tidak diterbitkan, Semarang: PPs. Universitas Diponegoro, 2010.

"Was-Was" dalam http://www.voutube.com/watch?v=GWgsX29kNis, diakses 4 Mei 2013.

Yunus, Mahmud, Hukum Perkawinan dalam Islam, cet. ke-8, Jakarta: Hidakarya Agung, 1979.

Zahrah, Muhammad Abu, Usui al-Figh, Kairo: Dar al-Fikr al-'Arabi, 1958.

Zalyunia, Dwi, "Tinjauan Yuridis Keputusan Mahkamah Konstitusi Nomor 46/PUUVIII/2010Terhadap Anak Luar Kawin Dihadapkan Dengan Kompilasi Hukum Islam dan Undang-Undang Nomor 1 Tahun 1974 Tentang Perkawinan", Tesis, tidak diterbitkan, Depok: Fakultas Hukum Program Magister Kenotariatan, 2012.

Zarqa, Mustafa Ahmad az-, al-Fiqh al-Islami fi S|aubihi al-Jadid, vol. I, Beirut: Dar al-Fikr, 1967.

Zuhaili, Wahbah az-, al-Fiqh al-Islami wa Adillatuh, cet. ke-1, vol. VII, Damaskus: Dar al-Fikr, 1987

, al-Fiqh al-Islami wa Adillatuhu, cet. ke-3, vol. VII, Beirut: Dar al-Fikr, 1989.

, al-Figh al-Islami wa Adillatuhu, vol. VIII, Beirut: Dar al-Fikr, 1968.

, Usul al-Fiqh al-Islami, Beirut: Dar al-Fikr, 1986. 